Volume: 12 Issue: 2 Year: 2015

\title{
Family perspective on home visiting program ${ }^{1}$
}

\author{
Sebahattin Ziyanak ${ }^{2}$ \\ Hakan Yagci ${ }^{3}$
}

\begin{abstract}
This study focused on a lately constructed survey instrument that was intended to test the family perspective on a home visiting program and school. The four areas investigated were parentteacher communications, student-teacher interactions, the parent's perception of the school and the parents' understanding of the home visiting program. The participants were selected from parents/guardians of 7th, 8th, 9th and 10th grade students at a Charter school in a southwestern major city in Texas, the United States of America. Twenty-two questions were asked to evaluate parent's viewpoint with the four designated areas of interaction and communication of among school-parent-teacher. The findings showed that $73.5 \%$ of the students' families living were in low income. The outcomes for reliability were promising $(\alpha=.909)$. Yet, the factor analysis outcomes of a rotated four-factor solution were insufficient to assess validity. This might be related to a small sample size $(n=45)$.
\end{abstract}

Keywords: Home visiting program; parent-teacher communications; student-teacher interactions; American educational system; the parent's perception of the school.

\section{Introduction}

It is obvious that there are many problems which need to be addressed and solved to improve the American educational system, such as the adaptation of bilingual and immigrant students, improvements of math and science education, etc. The intention of this paper is to examine the parents' perspective about a home visiting program which is believed to be helpful and effectual in improving the school involvement of these families who are mostly at high-risk.

\section{Literature Review}

The home visiting approach is described by Smith (1995) as a set of services provided to families in their homes instead of the more traditional methods of seeing the family or individual at school. It

\footnotetext{
1 Presented at the Southwest Educational Research Association (SERA), February 4 -6, 2014 San Antonio, Texas. (http://sera-edresearch.org/)

2 Ph.D., Adjunct Faculty, Sociology Department, College of Arts \& Science, University of Texas of Permian Basin, Odessa, Texas, USA, ziyanak s@utpb.edu, sebahattinziyanak@yahoo.com

3 Ph.D., Candidate, All but dissertation, University of North Texas, College of Education, Education Psychology Department, Denton, Texas, USA, hakanyagci@my.unt.edu
} 
is mentioned that home visiting gives teachers a chance to see and understand the home environment of the student and parent (Smith, 1995). It is used for several different purposes such as the provision of social services, and for fostering mental health, nutrition, and educational needs (Smith, 1995). It is also stated in different research contexts that it is useful for working with students with special needs both at home and in the school environment in harmony to reach the goal of these home visits (Scott and Law, 1994).

The home visits are also considered a responsibility of school, and schools that reach out in this way show they care about the children and parents' needs (Keller, 1997). Johnson (2001) explains that the aim of home visits is to increase student achievement by building strong relationships with families who are low income and do not have much time to come school and follow their kids progress at school. Home visiting gives parents a chance to express their beliefs and opinions about their children's education.

The positive effect of parental involvement in school activities is that it assists the students to succeed academically. Some of the positive processes involved are assisting their kids in assignments and projects, making available more time for them and providing supplies for their studies, as well as having improved communication with teachers and staff (Reglin, 2002).

According to Reglin (2002)'s research, home visitation can increase the family involvement in the schools' activities and academics. In addition, it was stated that family involvement is the best predictor of academic success for students (Reglin, 2002).

It is important that teachers establish friendly communications and interactions with parents that can increase mutual understanding and active involvement of the parent in the student's school related activities.

Home visits help teachers to know the parents better which also leads to changes in the way teachers think about students. These visits also change the parent's perspective of the teacher, and of the school, positively. They see the visits as a treat instead of a threat (Acosta and Keith, 1997, Sandham, 1999). It is reported also that home visited students' grades improved up to $20 \%$ (Acosta and Keith, 1997).

Parental involvement is very important for bilingual students attending school. Schools try to reach these parents and one of the most effective ways of being accessible and approachable is home visits (Clark and Dorris, 2007).

This is important because bilingual and immigrant students often have difficulties in adapting and succeeding in their education activities in the school, and their teachers have a very important duty to understand the relationship between those students' home culture and the academics at the 
school (Nash-Peralta, 2003). During the adaptation and adjustment phase to the new culture, language and life style, these students need extra assistance from teachers, and the school.

There are some difficulties in making home visits, for example it is time consuming, and difficult to organize teachers, however when the obstacles are overcome, it is well worth effort (Keller, 1997).

\section{Sample}

The participants for this study were parents/guardians of $7^{\text {th }}, 8^{\text {th }}, 9^{\text {th }}$ and $10^{\text {th }}$ grade students at a Charter school in a southwestern major city. This school has $73.5 \%$ of the students defined as disadvantaged (low income), and $72.6 \%$ of its students are Hispanic, 9.2 \% of them are AfricanAmerican students. The $71 \%$ of parents who returned the survey that was analyzed, were female. Most (64.4\%) parents were Hispanic. 51.1\% of the parents had one child in this school, $31.1 \%$ had 2 children, $8.9 \%$ had 3 children and $8.9 \%$ had 4 or more children. At more than half of homes $(60$ $\%)$, Spanish was the main spoken language.

\section{Method}

The survey items were developed from the literature on home visiting and parent involvement and parent support programs. The survey did not include any questions which asked for names and identifying information. The survey was reviewed by two experts (a secondary school teacher, and a parent who is teacher) for content validity. The irrelevant items were excluded, and two items included. The survey was delivered to parents of students. The surveys were handed out in 4 different classes to 80 students. The return rate of survey was $69 \%$ (55) and only 45 of them were analyzed because of missing data.

One definite limitation to this study involves the fact that only four classes, out of 14 classes, were used for the research although this was not the preferred sample size. In turn, survey results may be skewed. The survey was distributed to students to give their parents at a Charter school in a Southwestern major city. It was designed to measure the parents' perspective about home visiting program and its effects in relationships among parent-school-teacher that would stand in each of the four previously identified areas.

The survey has twenty-seven questions. The demographic areas investigated were 1) sex, 2) race, 3) number of children in the school, 4) relationship to child in the school, 5) main language spoken at home. The last 22 questions of the survey were designed to identify and measure the parent-teacher communication process, the student-teacher interactions, parent's perceptions of the school, and parents' understanding of the home visiting program. 


\section{Results}

For statistical analysis SPSS is used for coding. The survey was managed to 55 parents, however, the useable number of responses reduced to forty-five due to item non-responses. As mentioned above, an assed coefficient alpha of .909 with the twenty-two 22 question indicated very reasonable results in the area of parent's perspective with the four designated areas of interaction and communication of among school-parent-teacher. Previous literature within this filed has not found any comparable instrument that had been used for the same study object. In turn, comparison of the reliability of the instrument to other studies was not available. Please see Table 2 for the details of reliability analysis

Confirmatory factor analysis was piloted to measure the construct validity. Principal component analysis is used as the extraction method. Initial eigenvalues were calculated on twenty-two items to conclude the applicable number of factors to execute rotation on in order to best chance the simple structure criteria established by Thurstone (1942).

A possible six factor rotation was exposed for a scree plot analysis as well as the initial eigenvalues $(\lambda \geq 1.00)$. The initial extraction of factors showed that a four-factor solution would explain for $67.167 \%$ of the total variance. On the other side, a seven factor solution would explain for $77.468 \%$ of the total variance because lack of sample size.

Items between 1-9 performed to load on factor 1-Perception of teacher-student interaction. Items between 10-15 performed to load on factor 2- Perception of teacher-parent interaction. Items between 16-19 performed to load on factor 3- Perception of parents about home visiting. Items between 20-22 performed to load on factor 4- Perception of parents about school.

Results showed that some correlations and commonalities with other factors appeared as a results of twelve of the items are loaded on more than one factor. In other words, this inferred that the factors were not octagonal (factors rotated with varimax).

As demonstrated in Table 1 and Table 3, oblim or oblique rotations creates better loading than varimax rotation. Please see Table 1 and Table 3 for details concerning the scree plot, the initial eigenvalues, the component transformation matrix, and so on. 
Ziyanak, S., \& Yagci, H. (2015). Family perspective on home visiting program. International Journal of Human Sciences, 12(2), 477-484. doi:10.14687/ijhs.v12i2.3216

\section{Table 1}

Total Variance Explained

\begin{tabular}{|c|c|c|c|c|c|c|c|c|c|}
\hline \multirow[b]{2}{*}{ Component } & \multicolumn{3}{|c|}{ Initial Eigenvalues } & \multicolumn{3}{|c|}{ Extraction Sums of Squared Loadings } & \multicolumn{3}{|c|}{ Rotation Sums of Squared Loadings } \\
\hline & Total & $\%$ of Variance & Cumulative $\%$ & Total & $\%$ of Variance & Cumulative \% & Total & $\%$ of Variance & Cumulative $\%$ \\
\hline 1 & 9.808 & 44.584 & 44.584 & 9.808 & 44.584 & 44.584 & 4.835 & 21.977 & 21.977 \\
\hline 2 & 2.011 & 9.143 & 53.726 & 2.011 & 9.143 & 53.726 & 3.403 & 15.468 & 37.445 \\
\hline 3 & 1.619 & 7.360 & 61.086 & 1.619 & 7.360 & 61.086 & 2.451 & 11.143 & 48.588 \\
\hline 4 & 1.338 & 6.081 & 67.167 & 1.338 & 6.081 & 67.167 & 2.450 & 11.134 & 59.722 \\
\hline 5 & 1.229 & 5.586 & 72.753 & 1.229 & 5.586 & 72.753 & 1.989 & 9.042 & 68.764 \\
\hline 6 & 1.037 & 4.715 & 77.468 & 1.037 & 4.715 & 77.468 & 1.915 & 8.704 & 77.468 \\
\hline 7 & .964 & 4.382 & 81.850 & & & & & & \\
\hline 8 & .726 & 3.301 & 85.151 & & & & & & \\
\hline 9 & .604 & 2.745 & 87.896 & & & & & & \\
\hline 10 & .480 & 2.183 & 90.079 & & & & & & \\
\hline 11 & .460 & 2.090 & 92.168 & & & & & & \\
\hline 12 & .402 & 1.826 & 93.995 & & & & & & \\
\hline 13 & .336 & 1.526 & 95.520 & & & & & & \\
\hline 14 & .306 & 1.389 & 96.910 & & & & & & \\
\hline 15 & .252 & 1.145 & 98.055 & & & & & & \\
\hline 16 & .116 & .526 & 98.581 & & & & & & \\
\hline 17 & .088 & .402 & 98.983 & & & & & & \\
\hline 18 & .079 & .359 & 99.342 & & & & & & \\
\hline 19 & .061 & .277 & 99.619 & & & & & & \\
\hline 20 & .037 & .167 & 99.786 & & & & & & \\
\hline 21 & .026 & .118 & 99.904 & & & & & & \\
\hline 22 & .021 & .096 & 100.000 & & & & & & \\
\hline
\end{tabular}

Extraction Method: Principal Component Analys is.

\section{Scree Plot}

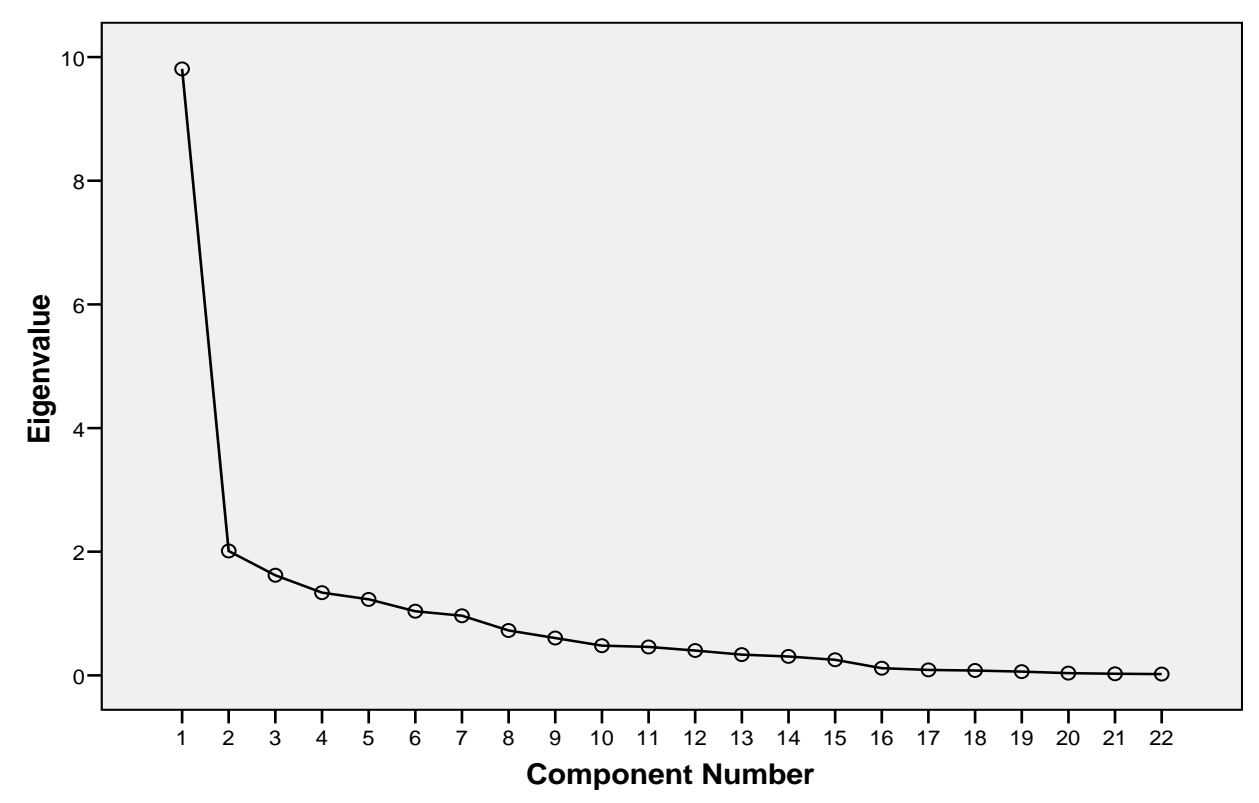


Ziyanak, S., \& Yagci, H. (2015). Family perspective on home visiting program. International Journal of Human Sciences, 12(2), 477-484. doi:10.14687/ijhs.v12i2.3216

\section{Table 2}

\begin{tabular}{|c|c|}
\hline Item-Total Statistics & \\
\hline & $\begin{array}{l}\text { Cronbach's Alpha if } \\
\text { Item Deleted }\end{array}$ \\
\hline $\begin{array}{l}\text { Teachers give students extra help with tutoring, and other scholastic } \\
\text { issues. }\end{array}$ & 0.903 \\
\hline Teachers help students respect others who are different from them. & 0.903 \\
\hline $\begin{array}{l}\text { Teachers give detailed information about homework assignments } \\
\text { and projects }\end{array}$ & 0.904 \\
\hline $\begin{array}{l}\text { Teachers make modifications and adjustments to meet individual } \\
\text { student's needs in classroom. }\end{array}$ & 0.903 \\
\hline Teachers' expectations from parents are well defined and clear. & 0.907 \\
\hline Teachers grade fairly. & 0.905 \\
\hline The communication between teachers and parents is effective. & 0.902 \\
\hline Teachers show equal respect to all students. & 0.904 \\
\hline The safe environment in the school promotes student learning. & 0.904 \\
\hline Teachers consistently improve communication with students. & 0.899 \\
\hline Teachers contact the parents of students who have discipline issues. & 0.907 \\
\hline $\begin{array}{l}\text { As a parent, I feel comfortable and safe when I am visited by a } \\
\text { teacher. }\end{array}$ & 0.903 \\
\hline I like to help with activities at school. & 0.903 \\
\hline Home visiting promotes my child's learning at home. & 0.901 \\
\hline Home visiting should be done every semester. & 0.900 \\
\hline Home visiting is a violation of privacy. & 0.924 \\
\hline $\begin{array}{l}\text { There are cultural/language/educational barriers that interfere with } \\
\text { our participation at school activities. }\end{array}$ & 0.924 \\
\hline $\begin{array}{l}\text { Teachers and staff like to contact families of students having } \\
\text { academic or behavior problems. }\end{array}$ & 0.903 \\
\hline The school has volunteer work, resources for families. & 0.905 \\
\hline We are treated with respect by teachers and school staff. & 0.905 \\
\hline Teacher care about my child as an individual. & 0.900 \\
\hline Teachers respond to my emails or phone calls in a timely manner. & 0.906 \\
\hline Cronbach's Alpha & $\begin{array}{r}\text { Cronbach's Alpha } \\
\text { Based on Standardized } \\
\text { Items }\end{array}$ \\
\hline 0.909 & 0.916 \\
\hline
\end{tabular}


Ziyanak, S., \& Yagci, H. (2015). Family perspective on home visiting program. International Journal of Human Sciences, 12(2), 477-484. doi:10.14687/ijhs.v12i2.3216

\section{Table 3}

\begin{tabular}{|c|c|c|c|c|}
\hline \multicolumn{5}{|l|}{ Rotated Component Matrix } \\
\hline & $\begin{array}{l}\text { Componen } \\
t\end{array}$ & & & \\
\hline & 1 & 2 & 3 & 4 \\
\hline Home visiting should be done every semester. & 0.836 & & & \\
\hline $\begin{array}{l}\text { The safe environment in the school promotes student } \\
\text { learning. }\end{array}$ & 0.789 & & & \\
\hline $\begin{array}{l}\text { Teachers respond to my emails or phone calls in a timely } \\
\text { manner. }\end{array}$ & 0.778 & & & \\
\hline Home visiting promotes my child's learning at home. & 0.745 & & & \\
\hline Teacher care about my child as an individual. & 0.724 & & & \\
\hline $\begin{array}{l}\text { Teachers consistently improve communication with } \\
\text { students. }\end{array}$ & 0.659 & & & \\
\hline $\begin{array}{l}\text { As a parent, I feel comfortable and safe when I am visited } \\
\text { by a teacher. }\end{array}$ & 0.639 & & & \\
\hline I like to help with activities at school. & 0.573 & & & \\
\hline $\begin{array}{l}\text { The communication between teachers and parents is } \\
\text { effective. }\end{array}$ & 0.507 & & & \\
\hline $\begin{array}{l}\text { Teachers give students extra help with tutoring, and other } \\
\text { scholastic issues. }\end{array}$ & & 0.808 & & \\
\hline $\begin{array}{l}\text { Teachers make modifications and adjustments to meet } \\
\text { individual student's needs in classroom. }\end{array}$ & & 0.802 & & \\
\hline $\begin{array}{l}\text { Teachers give detailed information about homework } \\
\text { assignments and projects }\end{array}$ & & 0.762 & & \\
\hline $\begin{array}{l}\text { Teachers help students respect others who are different } \\
\text { from them. }\end{array}$ & & 0.671 & & \\
\hline The school has volunteer work, resources for families. & & 0.608 & & \\
\hline $\begin{array}{l}\text { Teachers' expectations from parents are well defined and } \\
\text { clear. }\end{array}$ & & 0.494 & & \\
\hline $\begin{array}{l}\text { Teachers contact the parents of students who have } \\
\text { discipline issues. }\end{array}$ & & & 0.826 & \\
\hline $\begin{array}{l}\text { Teachers and staff like to contact families of students } \\
\text { having academic or behavior problems. }\end{array}$ & & & 0.812 & \\
\hline Teachers grade fairly. & & & 0.682 & \\
\hline Teachers show equal respect to all students. & & & 0.569 & \\
\hline $\begin{array}{l}\text { There are cultural/language/educational barriers that } \\
\text { interfere with our participation at school activities. }\end{array}$ & & & & 0.884 \\
\hline Home visiting is a violation of privacy. & & & & 0.678 \\
\hline We are treated with respect by teachers and school staff. & & & & 0.529 \\
\hline $\begin{array}{l}\text { Extraction Method: Principal Component Analysis. } \\
\text { Rotation Method: Varimax with Kaiser Normalization. }\end{array}$ & & & & \\
\hline
\end{tabular}




\section{Discussion \& Conclusion}

This was a pilot study that sought to assess the reliability and validity of an instrument designed to measure parents' perspective about home visiting program. As expected, the result of the alpha coefficient of .909 is very satisfactory. The lack of proper sample size is the main limitation for this analysis. Crocker and Algina (1986), note that a survey with twenty items must have had at least sample size of 200 and above.

Post hoc analysis of the 22 items specifies some certain overlap/duplication of items. Nonetheless, with a better sample size $(\mathrm{n} \geq 250)$ it is more likely to produce a rotated three-factor analysis solution which generates improved models for simple structure criteria. A larger sample is needed to have better the coefficient alpha value to measure the reliability of the survey instrument.

\section{References}

Acosta, D. and Keith, J. (1997). Home visits to middle-schoolers. Education Digest, 63(3), pp.49-50.

Clark, A.A. and Dorris, A.(2007). Partnering with Latino Parents. Education Digest: Essential Readings Condensed for Quick Review, 72(7), pp.44-50

Crocker, L. \& Algina, J. (1986). Introduction to Classical \& Modern Test Theory. Belmont, CA: Wadsworth Group.

Johnston, T. (2001). Home Work. Teacher Magazine, 12(6), p12.

Keller, B. (1997). House calls. Education Week, 17(1), pp.37-41.

Nash-Peralta, C. (2003). The Impact of Home Visit in Students' Perception of Teaching. Teacher Education Quarterly, 30(4), pp.111-125.

Reglin, G. (2002). Project reading and writing (R.A.W.): Home visitations and the school involvement of high-risk families. Education, 123(1), pp.153-160.

Sandham, J. L. (1999). Home visits lead to stronger ties, altered perceptions. Education Week, 19(14), p6.

Scott, S. J. and Law, S. (1994). Home visits: Partnership in education. Focus on Autistic Behavior, 8(6), pp.11-12.

Smith, L.E. (1995). Healthy families California: A review of standards and best practices in home visiting programs across California (Report No. PS 025769). Sacramento, CA: California Consortium to Prevent Child Abuse (ERIC Document Reproduction Service No. ED411952). 